\title{
Corrigendum: Semaphorin 4C: A Novel Component of B-Cell Polarization in Th2-Driven Immune Responses
}

\author{
Di Xue', Marylin Desjardins',2, Gabriel N. Kaufman', Marianne Béland', Salem Al-Tamemi' ${ }^{2,3}$, \\ Eisha Ahmed ${ }^{1}$, Shao Tao ${ }^{1}$, Roland H. Friedel ${ }^{4}$, Walid Mourad ${ }^{5}$ and Bruce D. Mazer,2* \\ ${ }^{1}$ Translational Research in Respiratory Diseases, The Research Institute of the McGill University Health Center, Montreal, QC, \\ Canada, ${ }^{2}$ McGill University Health Center, Montreal Children's Hospital, Montreal, QC, Canada, ${ }^{3}$ Sultan Qaboos University \\ Hospital, Muscat, Oman, ${ }^{4}$ Icahn School of Medicine at Mount Sinai, New York, NY, USA, ${ }^{5}$ Department of Medicine, \\ University de Montreal, Montreal, QC, Canada
}

Keywords: semaphorin 4C, B-cells, immune synapse, Th2 responses

\section{A Corrigendum on}

Semaphorin 4C: A Novel Component of B-Cell Polarization in Th2-Driven Immune Responses by Xue D, Desjardins M, Kaufman GN, Béland M, Al-Tamemi S, Ahmed E, et al. Front Immunol (2016) 7:558. doi:10.3389/fimmu.2016.00558

There was a mistake in the name of the author Salem Al-Tememi as published. The correct spelling of the name should be Salem Al-Tamemi. The authors apologize for the mistake. This error does not change the scientific conclusions of the article in any way.

In the original article, we neglected to thank Immunodeficiency Canada for providing grant support for part of the study via the Chaim Roifman Award Program. The correct Funding section

Edited and Reviewed by: Barbara L. Kee,

University of Chicago, USA

${ }^{*}$ Correspondence: Bruce D. Mazer bruce.mazer@mcgill.ca

Specialty section: This article was submitted to $B$ Cell Biology,

a section of the journal Frontiers in Immunology

Received: 25 January 2017 Accepted: 15 February 2017 Published: 08 March 2017

Citation:

Xue D, Desjardins M, Kaufman GN, Béland M, Al-Tamemi S, Ahmed E, Tao S, Friedel RH, Mourad W and Mazer BD (2017) Corrigendum: Semaphorin 4C: A Novel Component of B-Cell Polarization in Th2-Driven Immune Responses.

Front. Immunol. 8:213. doi: 10.3389/fimmu.2017.00213 is below.

\section{FUNDING}

The authors acknowledge the financial support of Natural Sciences and Engineering Research Council (NSERC) Grant 47480, the Canadian Institute for Health Research (CIHR) Grant MOP142247, The Research Institute of the McGill University Health Center (RI-MUHC), Montreal Chest Institute, Costello Foundation, the Strauss Family Foundation and we thank the Immunodeficiency Canada for providing grant support for part of the study via the Chaim Roifman Award Program. BM was a Chercheur National of the Fonds de Recherche du Québec-Santé. MD was the recipient of a Strauss Fellowship from McGill University and the Allergen-NCE Clinician Scientist Award.

The authors apologize for this oversight. This error does not change the scientific conclusions of the article in any way.

The original article has been updated.

Conflict of Interest Statement: The authors declare that the research was conducted in the absence of any commercial or financial relationships that could be construed as a potential conflict of interest.

Copyright $\odot 2017$ Xue, Desjardins, Kaufman, Béland, Al-Tamemi, Ahmed, Tao, Friedel, Mourad and Mazer. This is an open-access article distributed under the terms of the Creative Commons Attribution License (CC BY). The use, distribution or reproduction in other forums is permitted, provided the original author(s) or licensor are credited and that the original publication in this journal is cited, in accordance with accepted academic practice. No use, distribution or reproduction is permitted which does not comply with these terms. 